\title{
Palaeoenvironmental conditions for human settlement at the Fuegian steppe (Argentina) based on diatom analysis. Lake Arturo as a case study
}

\author{
Marilén Fernández ${ }^{\mathrm{a}, *}$, Nora I. Maidana ${ }^{\mathrm{b}}$, J. Federico Ponce ${ }^{\mathrm{a}, \mathrm{c}}$, Jimena Oría ${ }^{\mathrm{a}}$, \\ Mónica Salemme ${ }^{\mathrm{a}, \mathrm{d}}$, Andrea Coronato ${ }^{\mathrm{a}, \mathrm{c}}$ \\ a Laboratorio de Geomorfología y Cuaternario, CADIC-CONICET, Ushuaia, Argentina \\ b Laboratorio de Diatomeas continentales, Departamento de Biodiversidad y Biología Experimental, Fac. Cs. Exactas y Naturales, UBA, IBBEA (CONICET-UBA), C. A. B. A., Argentina \\ ' Instituto Ciencias Polares, Recursos Naturales y Ambiente, ICPA-UNTDF Ushuaia, Argentina \\ d Instituto de Cultura, Sociedad y Estado, ICSE-UNTDF Ushuaia, Argentina
}

\section{A R T I C L E I N F O}

\section{Article history:}

Received 17 December 2016

Received in revised form 24 March 2017

Accepted 24 March 2017

Available online 5 July 2017

\section{Keywords:}

Tierra del Fuego

Shallow lake

Sedimentary record

Diatoms

Hunter-gatherers

\begin{abstract}
A B S T R A C T
This paper adds information on the palaeoenvironmental evolution in northern Tierra del Fuego, using subfossil diatom analysis. The archaeological evidence suggested the presence of hunter-gatherer groups during the Holocene at the Fuegian steppe. Some shallow lake basins have denser archaeological record than others; thus, it is interesting to evaluate and discuss if that might be related to different environmental conditions in the past. Lake Arturo offered opportunities for wildlife (guanacos and birds), and then, strategic meeting points for humans. A sediment core was taken from the lake with a Livingstone gravity corer. Diatom results suggest a brackish and shallow lake at Lake Arturo almost along the entire Holocene. The lacustrine basin started to desiccate during Middle Holocene or it had, at least, a similar configuration and dynamics as it has today. The diatom analysis is an interesting approach to evaluate how variable the local resources could have been in the studied lake, both on the spatial and the temporal scale, and the degree in which lakes could have affected or influenced the routes of hunter-gatherer mobility in the past.
\end{abstract}

C 2017 Published by Elsevier Ltd.

\section{Introduction}

The peopling of southernmost South America occurred during the end of the Late Glacial times (16,000 and 10,000 years BP), as it has been demonstrated in several sites of continental Patagonia (Borrero, 1999, 2008; Miotti, 2006; Miotti and Salemme, 1999; Salemme and Miotti, 2008; among others). Tierra del Fuego was the last southern tip to be explored and colonized by people after the Last Glacial Maximum (Borrero, 2004; Salemme and Miotti, 2008). Cultural and faunal remains recorded at Tres Arroyos 1 archaeological site (Fig. 1; Massone, 2004) proved that a group of hunters occupied the NW portion of the present island at ca. 10,500 yr ago, when Tierra del Fuego was still part of the continent (McCulloch et al., 2005; Rabassa, 2008). After a hiatus of approximately four thousand years since the Middle Holocene, the archaeological record denotes population increase (Salemme and Santiago, 2017).

In the northern part of Tierra del Fuego, between Chico and Grande rivers, the archaeological record was studied from a distributional perspective (Oría, 2014; Santiago, 2013). This criteria considers the archaeological record as a continuum with higher density peaks (Dunnell and

\footnotetext{
* Corresponding author.

E-mail address: shanamain@gmail.com (M. Fernández).
}

Dancey, 1983) which reflects human activity in a large space and not only where the action took place. In the study area, the shallow lake basin suggests a continuous and heterogeneous use of the inland environments of the Fuegian steppe during the Holocene (Oría, 2014).

The interaction between humans and environment has been an important topic in anthropological literature concerned with the perceptions and use of landscape by people in the past. At the Fuegian steppe, some shallow lake basins have denser archaeological record than others (Oría et al., 2014); thus, it is interesting to evaluate and discuss if that might be related to different environmental conditions in the past. For this reason, the use of several proxy analysis results is an accurate approach to reconstruct the palaeoenvironmental history of shallow Lake Arturo during the Holocene. Diatomological and archaeological records from the shallow Lake Arturo as case study are presented herein.

\section{Setting}

The climate of the region is temperate-cold, with mean temperatures of $10^{\circ} \mathrm{C}$ in summer and $1{ }^{\circ} \mathrm{C}$ in winter. The mean annual precipitation is $379 \mathrm{~mm}$ (Tuhkanen, 1992). Intense and strong winds are permanent in the steppe, blowing mainly from northwest-westsouthwest direction. The Aridity Index of 0.75 characterizes the hydric 


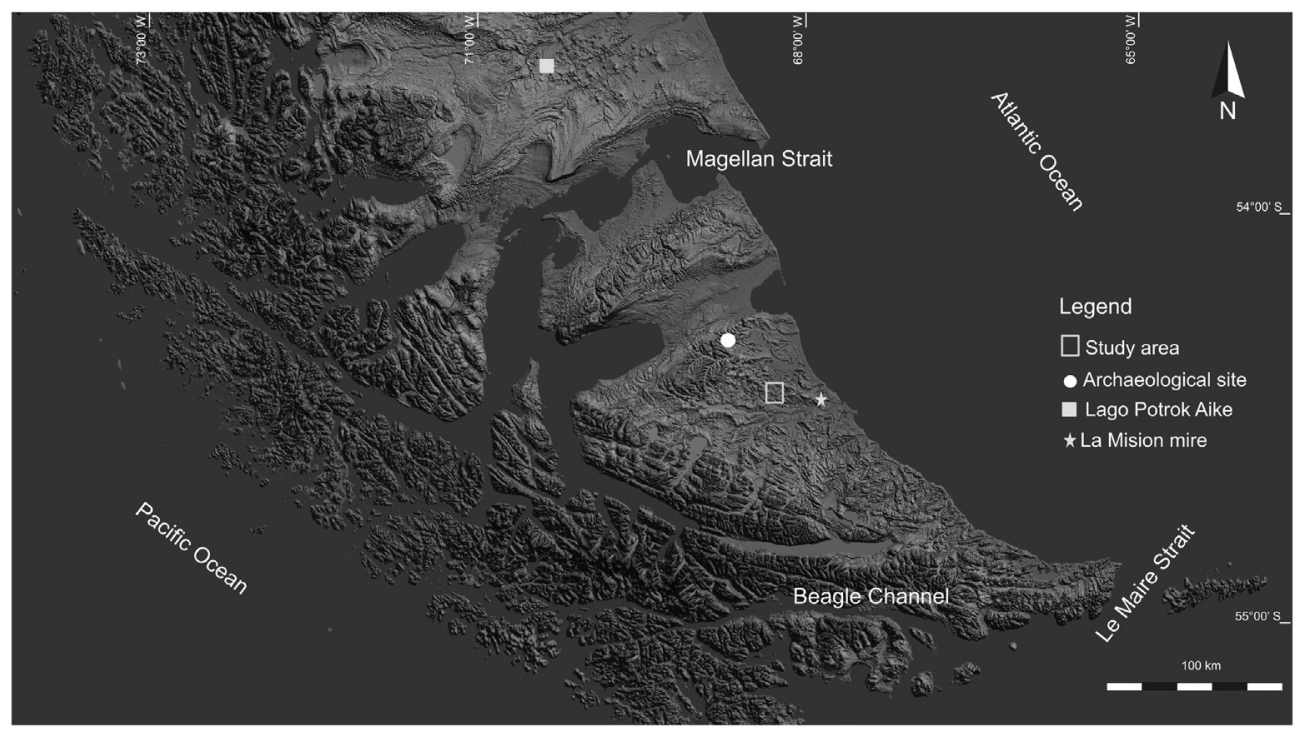

Fig. 1. Location of the study area and archaeological site.

regime for the Cold Subhumid Oceanic climate prevailing in this region (Coronato et al., 2008). The steppe vegetation is dominated by Festuca gracillima. Other species such as Azorella sp. and Nassauvia magellanica are also present.

\subsection{Study site}

Lake Arturo $\left(53^{\circ} 43^{\prime} \mathrm{S}, 68^{\circ} 18^{\prime} \mathrm{W}\right)$ is a shallow, saline, ephemeral, intermediate-sized water body located at $69 \mathrm{~m}$ a.s.l., in the semiarid steppe of northern Tierra del Fuego (Fig. 2A). It is located in a depression surrounded by smooth rocky hills covered by aeolian deposits. Almost circular in shape, its perimeter is $5.63 \mathrm{~km}$ long, the longest axis is $2.08 \mathrm{~km}$ long in the NE-SW direction, and the shortest axis is $1.6 \mathrm{~km}$ (Coronato et al., 2011). A cliff comprising $15 \mathrm{~m}$ of Neogene marine sedimentary rocks forms the southern shoreline of the lake. It is capped by $20.3 \mathrm{~m}$ of unconsolidated, fine-grained aeolian sediments (9 units), containing palaeosols (8 levels intercalated). The paleodune of Lake Arturo is exposed to northwest, north and northeast winds.

The maximum and mean water depths in the lake are unknown, but shallow waters are inferred by the authors from total desiccation of the lake during windy days in summer.

The studied shallow lake is settled on marine sedimentary rocks, which correspond to the Carmen Silva Formation (Codignotto and Malumián, 1981). This Formation has two members, the lower one of clay and sandy siltstones and the upper one of conglomerates and tuffs with abundant invertebrate fossils (Malumian and Olivero, 2006).

\subsection{Archaeological record}

Four archaeological sites were recorded in this lake -Arturo 1 (Coronato et al., 2011; Oría, 2014), Arturo 2 (Oría and Salemme, 2016), Arturo 3 and Arturo 4 (Oría et al., 2017), added to 12 isolated findings spread along the present lake coast. Bones and lithic artifacts

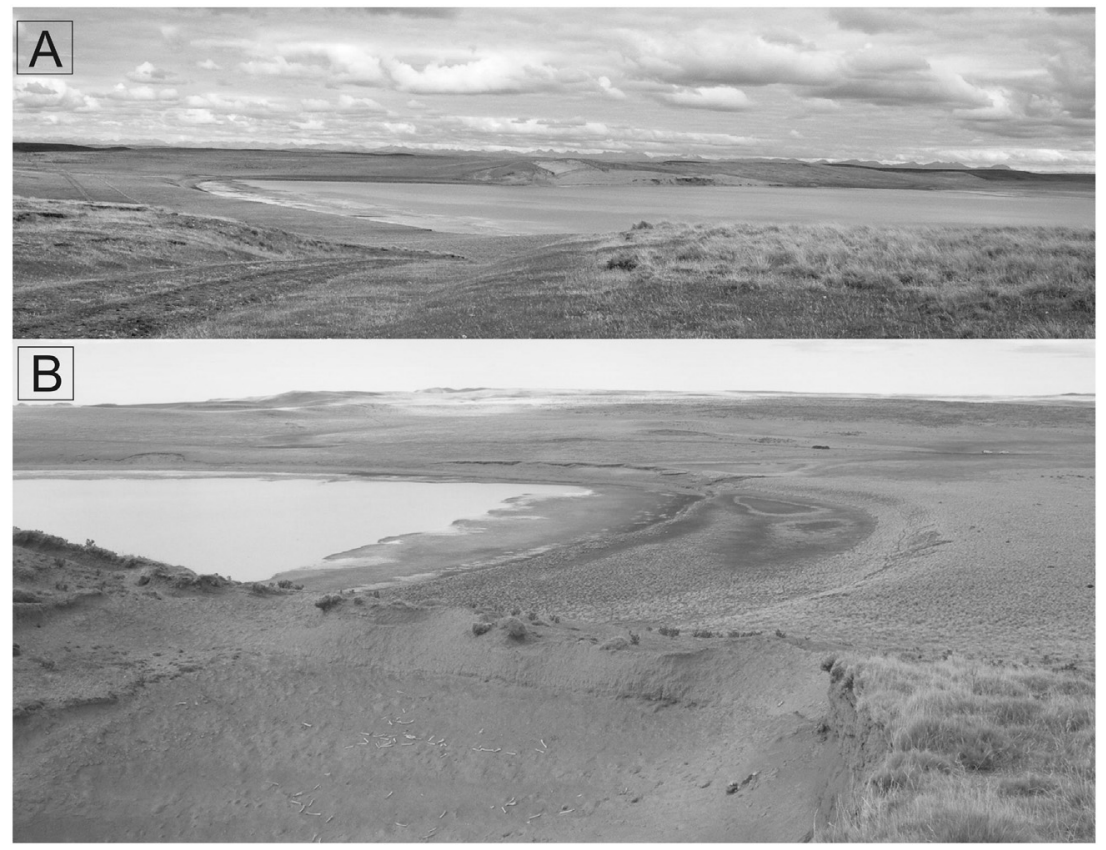

Fig. 2. Lake Arturo. A-Overview of Lake Arturo with its aeolian sequence on the south coast. B-Arturo 1 archaeological site in the deflation hollow. Note the ancient lacustrine terrace. 
were recorded at Arturo 1 but only very few bones could be assigned to human action (Fig. 2B; Oría et al., 2016). Instead, at Arturo 2 (Fig. 3), Arturo 3 and Arturo 4 sites, only lithic material was recorded; they were interpreted as differents loci of knapping activities (Oría et al., 2017, Oría and Salemme, 2016,).

In these assemblages, the absence of glass, iron or introduced fauna bones with anthropic marks suggests pre-European human occupations. Oría and Salemme (2016) suggested a human occupation around the shallow lake related to the exploitation of rocks as raw material; manufacture of scrapers is remarkable. The visibility of archaeological remains is associated to lake coastal erosion features. The archaeological material was found on the surface so there is no chronological control.

\section{Material and methods}

A sediment core was taken from the lake during the summer season of 2011, with a Livingstone gravity corer. The core of $166 \mathrm{~cm}$ long (LATF1) was retrieved when the shallow lake had just desiccated (Fig. 4). Diatom analyses were applied to the entire sedimentological record, but because of this work and considering the earliest ages of human occupation in Tierra del Fuego, we only focus and show the section of the core younger than $12,000 \mathrm{cal} \mathrm{BP}$.

Sub-samples for diatom analysis were taken every $1.25 \mathrm{~cm}$. Subsamples were first treated with $10 \% \mathrm{HCl}$, rinsed, and then heated with $30 \% \mathrm{H}_{2} \mathrm{O}_{2}$, at $80-90{ }^{\circ} \mathrm{C}$ for $2-3 \mathrm{~h}$ to oxidize the organic matter. Samples were rinsed repeatedly by suspending and dispersing the material in distilled water. The supernatant was discarded after $2 \mathrm{~h}$.

Permanent slides were mounted with Naphrax ${ }^{\circledR}$ and analyzed with a light microscope at $1000 \times$ magnification. At least 400 valves were counted in every slide. Diatom identification was primarily based on Husted (1930-1966), Krammer and Lange-Bertalot (1986, 1988, 1991a,b), Morales and Manoylov (2006) and Rumbrich et al. (2000).

The diatom stratigraphy was plotted with the Tilia and TGview Version 2.0.4 sofware (Grimm, 1992) and only species attaining $>3 \%$ in at least one sample were included. Diatom assemblages were grouped into two different zones using Coniss program by the method of constrained incremental sum of squares clustering (Grimm, 1992).

Three samples from Lake Arturo were radiocarbon dated (Table 1). AMS analyses were performed at DirectAMS ACCIUM Biosciences (Seattle, USA).The calibration curve was made by the software CALIB 7.0 (Stuiver et al., 2014) using the curve for Southern Hemisphere (SHcal13) (Hogg et al., 2013). The age-depth models were calculated with the OxCal 4.2.4 calibration software (Bronk Ramsey and Lee, 2013, Fig. 5).

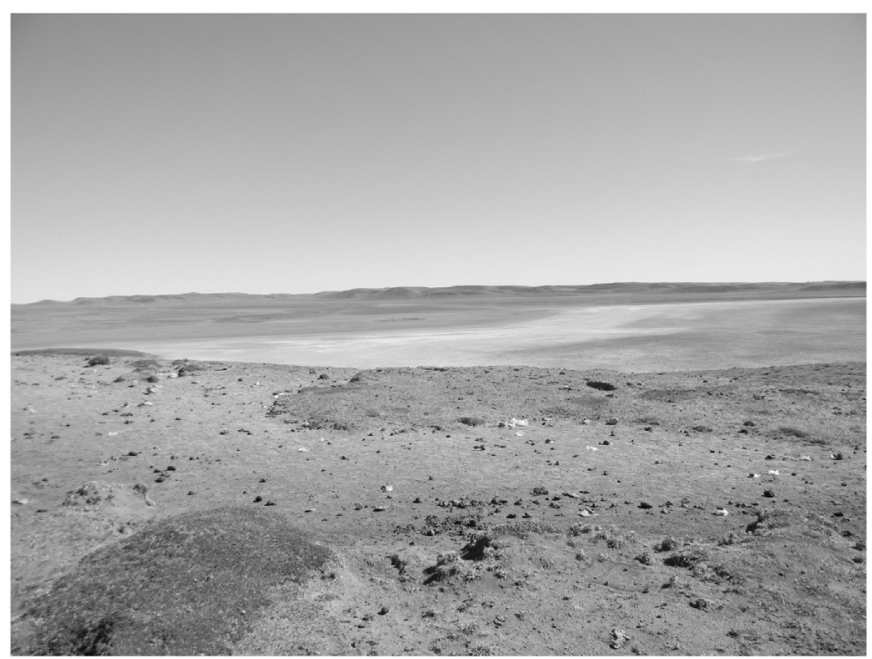

Fig. 3. Arturo 2 archaeological site.

\section{Results}

The total number of identified taxa was 99 . The species with $>3 \%$ relative abundance in at least one sample are shown in the Fig. 6.

\subsection{Zone I $(62-45 \mathrm{~cm})$}

\subsubsection{Subzone Ia: $62-55 \mathrm{~cm}(12,000-10,500 \mathrm{cal} \mathrm{BP})$}

The subzone is characterized by the dominance of epiphytic fragilarioid diatoms Staurosira venter (Ehrenberg) Cleve \& Moeller (60\%) and Staurosira binodis (Ehrenberg) Hustedt (40\%). Also, Staurosirella martyi (Héribaud) Morales \& Manoylov is present (15\%). Also present but less abundant there were other non planktonic taxa such as Epithemia adnata (Kützing) Brébisson, Epithemia sp., Pseudostaurosira brevistriata Williams \& Round, Diploneis elliptica (Kützing) Cleve, and Fragilaria capucina Desmazières.

\subsubsection{Subzone Ib: $55-45 \mathrm{~cm}(10,500-8200 \mathrm{cal} \mathrm{BP})$}

The dominant species in this subzone is the planktonic Thalassiosira patagonica N. Maidana (65\%) and some non-planktonic species have a minor frequency: Fragilaria capucina (15\%), Surirella brebissonii Krammer \& Lange-Bertalot, Pinnularia divergens W. Smith, Amphora sp., Cymbella sp., Navicula sp.. Surirella tuberosa O. Müller starts the subzone with $10 \%$ of relative frequency, increasing by the end of the subzone up to $35 \%$.

\subsection{Zone II $(45-10 \mathrm{~cm})$}

\subsubsection{Zone II: $45-10 \mathrm{~cm}$ ( $8200-1100$ cal BP)}

The dominant species is Surirella tuberosa $(80-85 \%$ of relative frequency). Representatives of Diploneis are present in almost the whole zone. Up to $25 \mathrm{~cm}$ depth they were identified as D. elliptica, but at $25-35 \mathrm{~cm}$ the poor preservation of the valves did not allow the species identification. Diploneis sp. is observed in the whole zone with frequencies reaching almost $40 \%$.

\section{Discussion}

\subsection{Diatom interpretation and comparison with paleoclimate data}

Around 12,000 cal BP, diatom assemblages of Lake Arturo are characterized by the dominance of fragilarioid taxa, which are primarily epiphytic, common in shallow waters and littoral areas of deep lakes. Most of them occur in circumneutral to alkaline, and oligotrophic to mesotrophic environments (Douglas and Smol, 2010). Lake Arturo might have had alkaline freshwater to brackish water. The dominance of epiphytic taxa, including Epithemia adnata, also suggests the presence of aquatic vegetation. Thus, it is interpreted as a shallow lake that presented a bottom covered with vegetation (Fig. 7). Indeed, glacier advance and increase in precipitation are reported for the Magellan Strait between 15,350 and 12,250 cal BP (McCulloch and Davies, 2001; McCulloch et al., 2005), which corresponds to the Antarctic Cold Reversal (ACR) cool event. This was followed by an arid phase in the Magellan area between $\sim 12,100$ and $\sim 9500$ cal yr BP (McCulloch et al., 2000).

At 10,500 cal BP, the diatom assemblage shows a remarkable change. Thalassiosira patagonica appears in the record and almost dominates it until $8200 \mathrm{cal} \mathrm{BP}$. This species was found in slightly brackish, nutrient rich and alkaline waters (Maidana, 1999). It is mentioned for the first time in Tierra del Fuego. The presence of this species might suggest a water input to the basin by surface runoff under more humid climatic conditions. The palaeomagnetic results of Lake Arturo palaeosoil 2 (Ps2) (between 11,304 and $7163 \mathrm{cal} \mathrm{BP}$ ) indicate that during its formation it presented higher water storage related with more humid climatic conditions than at present (Orgeira et al., 2012). Looking further north (approximately $250 \mathrm{~km}$ ), in continental Patagonia, at Laguna Potrok Aike $\left(52^{\circ} \mathrm{S}, 70^{\circ} \mathrm{W}\right.$, Fig. 1$)$ the record suggests warmer conditions for 


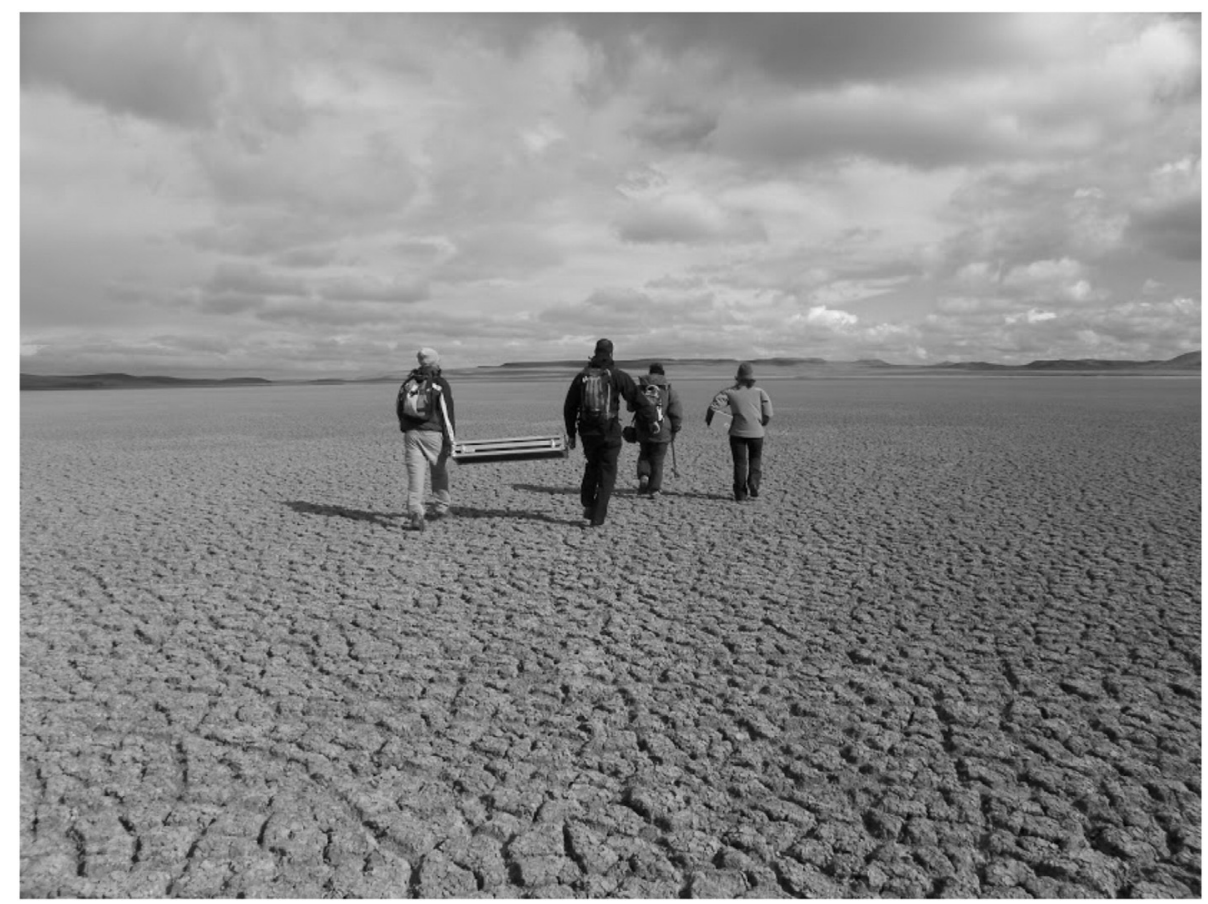

Fig. 4. Sampling activities at Lake Arturo.

this period (Massaferro et al., 2013; Recasens et al., 2015; Wille et al., 2007). This is a slightly brackish and deep lake where a palaeoenvironmental record that covers the last $c a 60,000$ years has been studied.

In Potrok Aike, Thalassiosira patagonica is observed for the same moment in the sediment record. It was interpreted as the beginning of lake's salinization and as an indicator of lower lake levels (Recasens et al., 2015). In Lake Arturo the relative abundance of Thalassiosira patagonica remains stable up to $8200 \mathrm{cal} \mathrm{BP}$. After $8200 \mathrm{cal} \mathrm{BP}$ up to 1100 cal BP, Surirella tuberosa, common in terrestrial and almost dry places (Frenguelli, 1924) dominates the assemblage. Besides, it appears along with Diploneis elliptica and Diploneis sp. Here, the assemblage suggests a brackish shallow to almost a desiccate lake.

At Laguna Potrok Aike between ca 8700 and 7300 cal BP sedimentation rates are the highest recorded for this lake and geochemical proxies suggest dry conditions with low lake levels (Haberzettl et al., 2007). Pollen, diatom, and chironomid records indicate that this was the driest and windiest part of the Holocene as well (Massaferro et al., 2013; Wille et al., 2007).

The sequence of aeolian deposits and palaeosoils of the perched dune in the Lake Arturo reflects a high variability in climate conditions since the Late Glacial-Holocene transition, when the last glacial recession occurred in Tierra del Fuego (Coronato et al., 2011; Orgeira et al., 2012). The aeolian deposition in this dune suggests a relative low sediment accumulation during the Early Holocene, being the peak between 6538 and $5552 \mathrm{cal} \mathrm{BP}$ and after that it declines (Coronato et al., 2011). This is coincident with what it is inferred from the dominance of $S$. tuberosa in the diatom assemblages. It is interesting to note that at $6538 \mathrm{cal} \mathrm{BP}$ the magnetic parameters of Lake Arturo Ps4 suggest periods of higher moisture related to higher precipitation (Orgeira et al., 2012).
Nevertheless, this event was not reflected in the diatom assemblage's composition.

Under a regional point of view, pollen analysis of La Misión mire (Fig. 1, Markgraf, 1976) showed a strong decrease in pollen frequencies during the last 3000 cal BP suggesting a regional climatic change. The climate might have turned drier, giving as a result a forest retraction. This phase drives to the current environment that corresponds to a grass steppe without trees, with $<500 \mathrm{~mm}$ annual precipitation (Markgraf, 1976).

High lake levels at Laguna Potrok Aike were identified at $1980 \mathrm{cal} \mathrm{BP}$, ca. 950-750 cal BP and ca. 530-20 cal BP (Haberzettl et al., 2005). Also at Lake Arturo, the magnetic parameters of the Ps7 (at ca. 471 cal BP) suggest a humid period (Orgeira et al., 2012).

\subsection{Archaeology and palaeoenvironmental scenarios in the Fuegian steppe}

Environmental conditions, inferred from the palaeoenvironmental studies and their relationship with past human groups, play a remarkable role for a better understanding of the formation processes in the archaeological record. At a large scale, natural environments represent an influence factor for human behavior (Dearing, 2006). In this sense, shallow lakes in semiarid environments constitute archaeologically interesting places, as they are considered to have been meeting points for hunter-gatherers and wildlife in the past.

The map of archaeological records in the Fuegian steppe is conformed mainly by many surface findings. The archaeological remains were registered in pans eroded by deflation on former dunes, lacustrine terraces or on their dry lake-bed (Coronato et al., 2011; Oría, 2014). Even considering the fact that water availability is a strong and important issue in hunter-gatherer lifestyles, the higher density of

Table 1

Radiocarbon samples and calibrated ages obtained at Lake Arturo (LATF1) core.

\begin{tabular}{|c|c|c|c|c|c|c|}
\hline Sample no. & Analysis no. & Sample material & ${ }^{14} \mathrm{C}$ age (BP) & $1 \sigma$ error & Calibrated ages & Depth $(\mathrm{cm})$ \\
\hline LATF2/13 & D-AMS 014411 & Bulk sediment & 1110 & 29 & 1000 & 13 \\
\hline LATF2/72 & D-AMS 014412 & Bulk sediment & 12,411 & 45 & 14,500 & 72 \\
\hline LATF2/163 & D-AMS 014413 & Bulk sediment & 18,960 & 66 & 22,800 & 163 \\
\hline
\end{tabular}




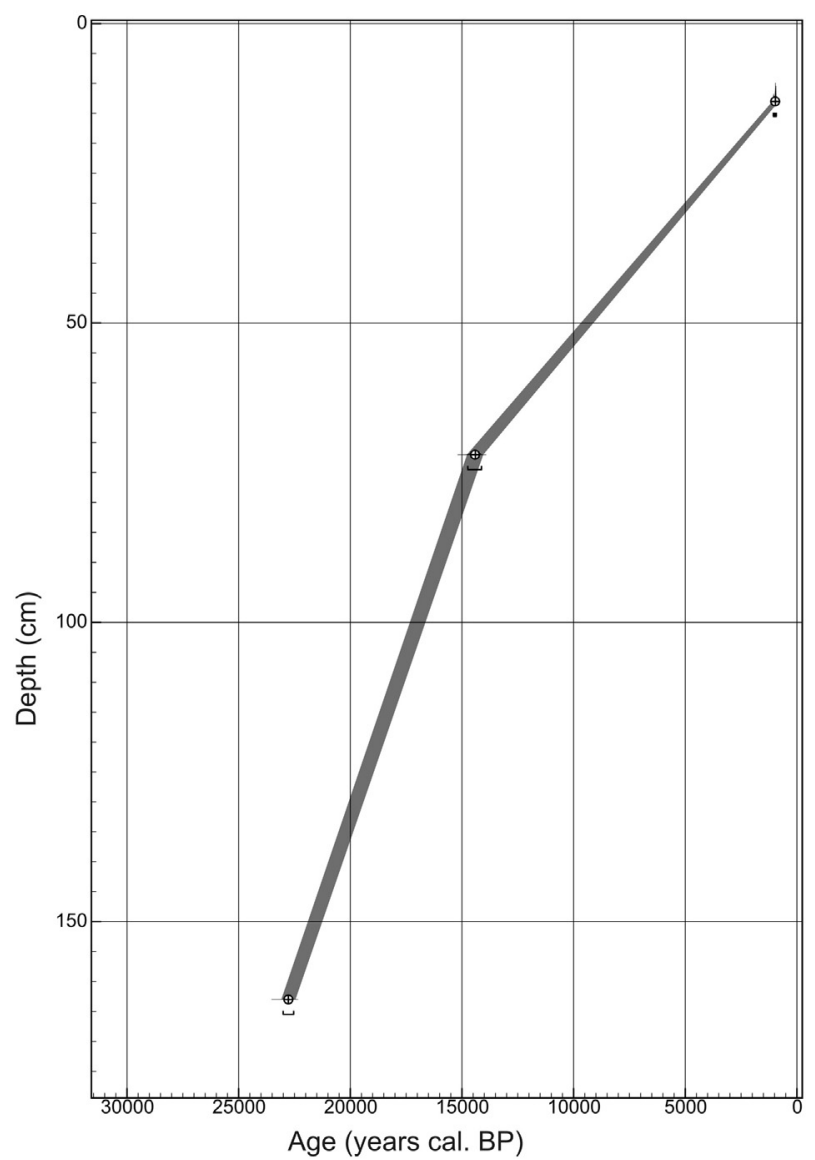

Fig. 5. Age-depth curve from Lake Arturo.

archaeological record in Lake Arturo than in nearby lakes could be linked to other circumstances, including acquisition of lithic raw material, and aspects related to the archaeological record itself: visibility, loss and preservation. An interesting point here is that even though there are many shallow lakes in the steppe, not all of them have the same amount and distribution of artifacts. The variability related to the use of the space is clear (Oría, 2014). Lake Arturo was included in a recurrent use pattern (Oría and Salemme, 2016).
Diatom results suggest a brackish and shallow lake at this site almost along the entire Holocene. The lacustrine basin started to desiccate during Middle Holocene or at least it had a similar configuration and dynamics as it has today. However, the geomorphological analyses in several lake basins at the Fuegian steppe suggests that they were larger than today according to the presence of terraces in higher positions (Coronato et al., 2012).

Diatom assemblages, mainly T. patagonica, in Lake Arturo showed that the waters were not optimal for human consumption. So, the use of the lacustrine environment seems to be more related to exploitation of raw material and, probably, to chase for wildlife. This inference gives us an idea of the activities that people developed around this water bodies, but it does not explain differences found in the distribution of archaeological record, at least in Lake Arturo.

The mobility strategies followed by hunter-gatherer groups might not be related to their subsistence exclusively; it could be related, as well, to a social meaning that makes particular points of landscape more attractive to people. To understand the occupation at Lake Arturo, we will use the concept of stopping point (sensu Stafford, 1995) to evaluate how human groups move around in the space (Oría et al., 2014). This author considers different landforms as "elements" that shape the landscape; those landforms with high density of findings are interpreted as stopping points (Stafford, 1995). The factor that turns certain elements into a stopping point needs further research to understand decisions taken by humans in the past. In our case study the availability of resources would not be a main vector to drive reoccupation. In this sense, the different human interactions with the environment is recognized to operate not through a given natural environment but rather on culturally built perceptions of that environment (Tilley, 1994).

\section{Conclusions}

The diatom assemblages recovered from sediment records from Lake Arturo provided environmental information to shed further light on the past ecological scenarios at the Fuegian steppe for human life. In general, the environments during the Holocene had been developed mainly under very windy conditions, highly dynamic cycles of dry and humid periods with variable rainfall rates and temperature.

For the Early Holocene, diatom assemblages at Lake Arturo suggest more precipitations and a lake turning to more brackish waters. Nevertheless, other humid cycles reflected in the palaeosoils sequence were not reflected in the diatom assemblages.

Even the unknown chronological human occupation around Lake Arturo we conclude, that during the Holocene, the lake could not offer

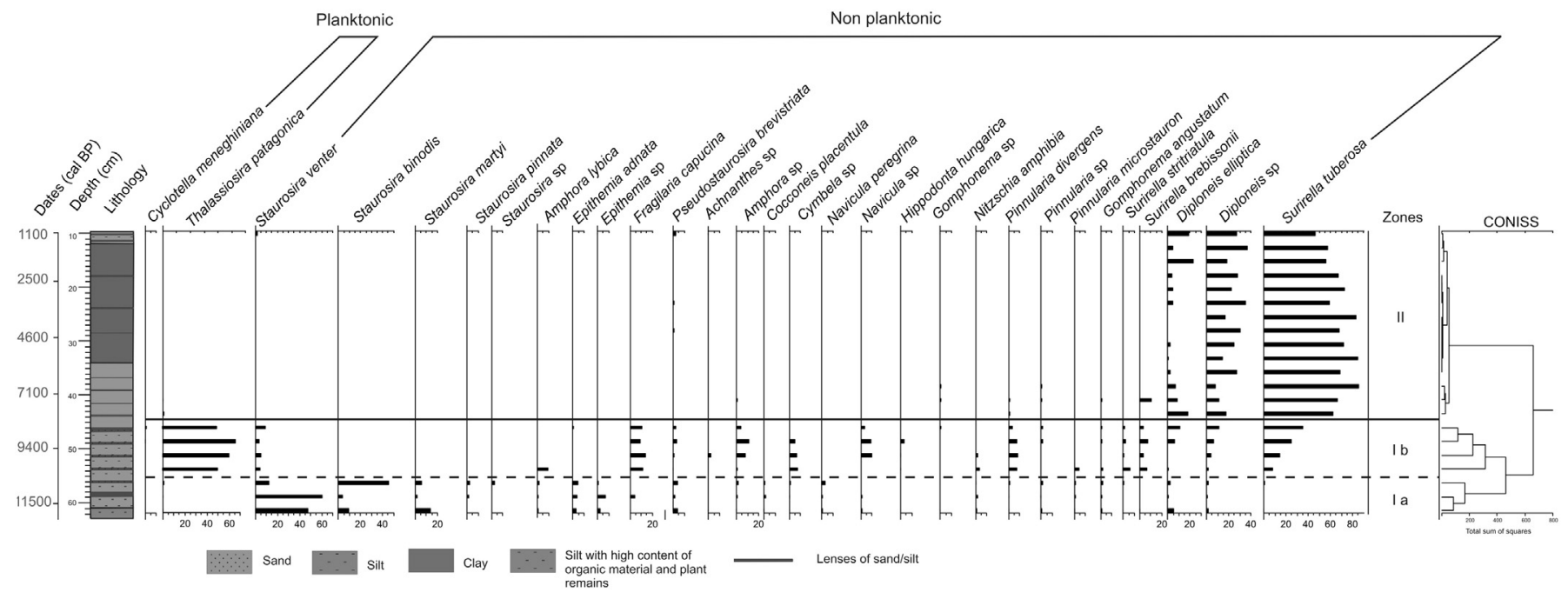

Fig. 6. Relative abundance of the main diatom species ( $>3 \%$ ) at Lake Arturo sediment record during the Late Pleistocene-Holocene. 
Palaeoenvironmental evolution at Lake Arturo

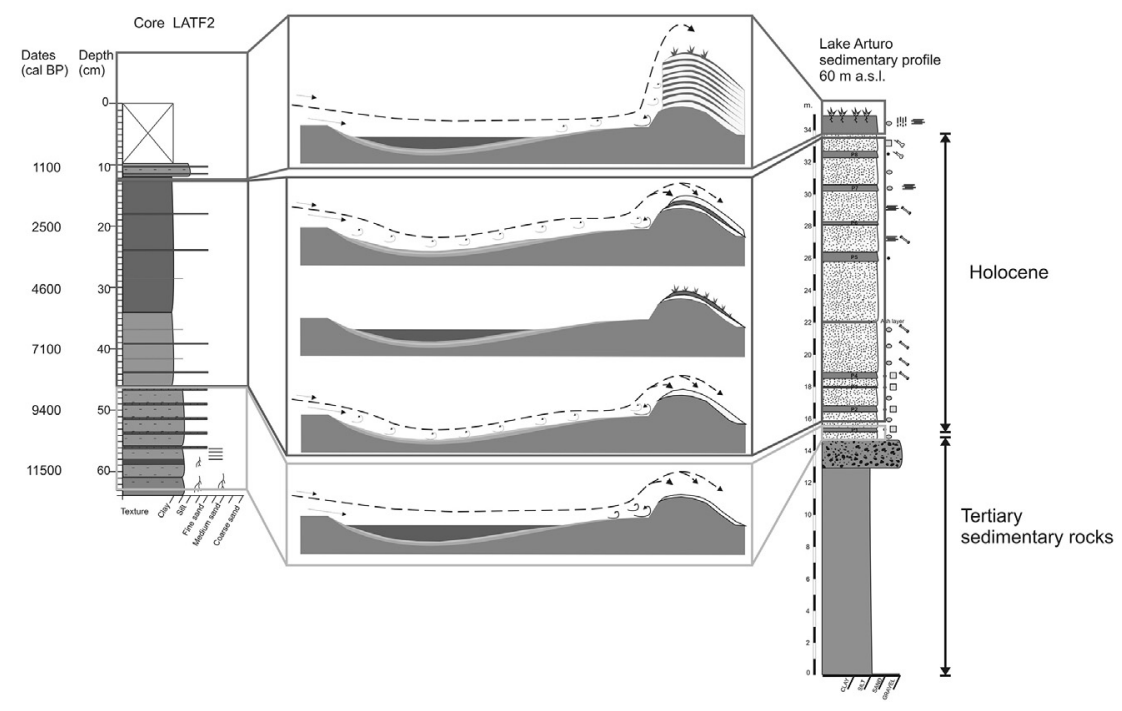

Fig. 7. Palaeoenvironmental evolution at Lake Arturo considering diatom data and compared to the lacustrine profile with the sequence of paleosoils formed in its south coast.

another possibility of use rather than the fauna hunting and/or lithic exploitation. According to the diatom record, all along the Holocene, Lake Arturo had brackish waters not suitable for human consumption. Since then, the lake seems to have had a semipermanent character with a highly dynamic desiccation and erosion.

\section{Acknowledgements}

Dra. Cecilia Laprida, Dra. Natalia Garcia Chapori and Tec. Ramiro López retrieved the cores. Lic. Ignacio Magneres took samples for radiocarbon dating. The Managers of Estancias San Julio and Flamencos allow us to work in their private lands. Dr. F. Santiago read a previous version of the manuscript. Two anonymous reviewers gave valuable comments to improve our manuscript. To all of them we would like to express our sincere thanks. Also, we thank the guest editors for their kind invitation to publish our results in this volume. This work was funded by PICT ANPCYT 2012-0628 (to AC) and 2012-1944 (to MS).

\section{References}

Borrero, L.A., 1999. Human dispersal and climatic conditions during Late Pleistocene times in Fuego-Patagonia. Quat. Int. 53 (54), 93-99.

Borrero, L.A., 2004. Arqueología en América del Sur. ¿Se requiere un acercamiento teórico especial? In: Politis, G., Peretti, R. (Eds.), Teoría arqueológica en América del Sur. vol. 3. Olavarria, INCUAPA - UNICEN, Serie Teórica, pp. 71-83.

Borrero, L.A., 2008. Early occupation in the Southern Cone. In: Silverman, H., Isbell, W.H. (Eds.), Handbook of South American Archaeology. Springer, New York, pp. 59-77.

Bronk Ramsey, C., Lee, S., 2013. Recent and planned developments of the program OxCal. Radiocarbon 55 (2-3), 720-730.

Codignotto, J., Malumián, N., 1981. Geología de la Región al N del paralelo 54 L.S. de la 435 Isla Grande de Tierra del Fuego. Rev. Asoc. Geol. Argent. 36 (1), 44-88.

Coronato, A., Coronato, F., Mazzoni, E., Vázquez, M., 2008. Physical geography of Patagonia and Tierra del Fuego. In: Rabassa, J. (Ed.), Late Cenozoic of Patagonia and Tierra del Fuego. Development in Quaternary Sciences vol. 11, 3. Elsevier, pp. 13-56.

Coronato, A., Fanning, T., Salemme, M., Oría, J., Pickard, J., Ponce, J.F., 2011. Aeolian sequence and the archaeological record in the fuegian steppe, Argentina. Quat. Int. $245,122-135$.

Coronato, A., Llopiz, S., Ponce, J.F., Villarreal, M.L., López, R., 2012. Paleorelieves lacustres en la estepa fueguina: ¿expansión-retracción asociada a cambios ambientales durante el Holoceno? V Congreso Argentino de Cuaternario y Geomorfología. Universidad Nacional de Río Cuarto, Río Cuarto, Córdoba, p. 82

Dearing, J.A., 2006. Climate-human-environment interactions: resolving our past. Clim. Past 2, 187-203.

Douglas, M.S.V., Smol, J.P., 2010. Freshwater diatoms as indicators of environmental change in the High Artic. In: Smol, J.P., Stoermer, E.F. (Eds.), The Diatoms: Applications for the Environmental and Earth Sciences, second ed Cambridge University Press, Cambridge, pp. 249-266.
Dunnell, R.C., Dancey, W., 1983. The siteless survey: a regional scale data collection strategy. In: Schiffer, M. (Ed.), Advances in Archaeological Method and Theory. vol. 6, pp. 267-287 (New York).

Frenguelli, J., 1924. Diatomeas de la Tierra del Fuego. Anales de la Sociedad Científica Argentina (96:225-263; 97:87-118, 231-266; 98:63).

Grimm, E.C., 1992. Tilia and tiliagraph: pollen spreadsheet and graphics programs. Programs and Abstracts, 8th International Palynological Congress, Aix-en-Provence, September 6-12, p. 56.

Haberzettl, T., Fey, M., Lücke, A., Maidana, N., Mayr, C., Ohlendorf, C., Schäbitz, F., Schleser, G.H., Wille, M., Zolitschka, B., 2005. Climatically induced lake level changes during the last two millennia as reflected in sediments of Laguna Potrok Aike, southern Patagonia (Santa Cruz, Argentina). J. Paleolimnol. 33, 283-302.

Haberzettl, T., Corbella, H., Fey, M., Janssen, S., Lücke, A., Mayr, C., Ohlendorf, C., Schäbitz, F., Schleser, G.H., Wille, M., 2007. Lateglacial and Holocene wet-dry cycles in southern Patagonia: chronology, sedimentology and geochemistry of a lacustrine record from Laguna Potrok Aike, Argentina. The Holocene 17 (3), 297-310.

Hogg, A.G., Hua, Q., Blackwell, P.G., Buck, C.E., Guilderson, T.P., Heaton, T.J., Niu, M., Palmer, J.G., Reimer, P.J., Reimer, R.W., Turney, C.S.M., Zimmerman, S.R.H., 2013. SHCal13 Southern Hemisphere calibration, 0-50,000 yrs cal BP. Radiocarbon 55 (4) (1889-445 1903).

Husted, F., 1930-1966. Die kieselalgen Deutschlands, Österreichs und der Schweiz unter Berücksichtung der übrigen Länder Europsas sowie der angrenzenden Meersgebiete. Akad. Verlag, Dr. L. RabenhorstsKryptogamen-Flora, 7 Leipzig.

Krammer, K., Lange-Bertalot, H., 1986. Bacillariophyceae. 1. Teil: Naviculariaceae. Süssewasser-flora von Mitteleuropa. Gustav Fisher Verlag, S, New York (876 pp).

Krammer, K., Lange-Bertalot, H., 1988. Bacillariophyceae. 2. Teil: Bacillariaceae Epithemiaceae, Surirellaceae. Süssewasser-flora von Mitteleuropa. Gustav Fisher Verlag, S, New York (596 pp).

Krammer, K., Lange-Bertalot, H., 1991a. Bacillariophyceae. 3. Teil: Centrales, Fragilariaceae, Eunotiaceae. Süssewasser-flora von Mitteleuropa. Spektrum Akademischer Verlag Heidelberg, Berlin (598 pp).

Krammer, K., Lange-Bertalot, H., 1991b. Bacillariophyceae. 4. Teil: Achnanthaceae, Kritische Ergänzungen zu Navicula (Lineolatae) un Gomphonema. Süssewasserflora von Mitteleuropa. Gustav Fisher Verlag, S, New York (437 pp).

Maidana, N., 1999. Thalassiosirapatagonicaspnov.(Thalassiosiraceae, Bacillariophyceae), a new lacustrine centric diatom from Santa Cruz, Argentina. Diatom Res. 14 (2), 323-329.

Malumian, N., Olivero, E., 2006. El Grupo Cabo Domingo, Tierra del Fuego: Bioestratigrafía, Paleoambientes y Acontecimientos del Eoceno-Mioceno marino. Rev. Asoc. Geol. Argent. 61 (2), 139-160.

Morales, E., Manoylov, K., 2006. Morphological studies on selected taxa in the genus Staurosirella Williams \& Round (Bacillariophyceae) from rivers in North America. Diatom Res. 21 (2), 343-364.

Markgraf, V., 1976. Nuevos datos para la historia vegetacional del tardiglacial y postglacial de "La Mision", Tierra del Fuego, Argentina. Memorias del III Coloquio sobre Paleobotánica y Palinología, pp. 75-80.

Massaferro, J., Recasens, C., Larocque-Tobler, I., Zolitschka, B., Maidana, N.I., 2013. Major lake level fluctuations and climate changes for the past 16,000 years as reflected bydiatoms and chironomids preserved in the sediment of Laguna PotrokAike, southern Patagonia. Quat. Sci. Rev. 71, 167-174.

Massone, M., 2004. Los cazadores después del hielo. Colección de Antropología 7, Ediciones de la Dirección de Archivos y Museos (173 pp).

McCulloch, R., Davies, S.J., 2001. Late glacial and Holocene palaeoenvironmental changes in the central Strait of Magellan, southern Patagonia. Palaeogeogr. Palaeoclimatol. Palaeoecol. 173, 143-173. 
McCulloch, R.D., Bentley, M.J., Purves, R.S., Hulton, N.R.J., Sugden, D.E., Clapperton, C.M., 2000. Climatic inferences from glacial and palaecological evidence at the last glacia termination, southern south America. J. Quat. Sci. 15 (4), 409-417.

McCulloch, R.D., Bentley, M.J., Tipping, R.M., Clapperton, C.M., 2005. Evidence for lateglacial ice dammed lakes in the central Strait of Magellan and Bahía Inútil, southernmost South America. Geogr. Ann., Ser. A 87, 335-362.

Miotti, L., 2006. La fachada atlántica, como puerta de ingreso alternativa de la colonización humana deAmérica del Sur durante la transición Pleistoceno/Holoceno. 2do Simposio Internacional El Hombre Temprano en América. CONACULTA-INAH, México, pp. 155-188.

Miotti, L., Salemme, M., 1999. Biodiversity, taxonomic richness and specialists-generalista during Late Pleistocene/Early Holocene times in Pampa and Patagonia (Argentina, Southern South America). Quat. Int. 53/54, 53-68.

Orgeira, M.J., Vasquez, C.A., Coronato, A., Ponce, J.F., Moreto, A., Osterrieth, M., Egli, R., Onorato, R., 2012. Magnetic properties of Holocene edaphized silty aeolian sediments from Tierra del Fuego (Argentina). Rev. Soc. Geol. Esp. 25 (1-2), 45-56.

Oría, J., 2014. Tierra adentro. Distribuciones artefactuales y movilidad en la estepa fueguina. In: Oría, J., Tívoli, A.M. (Eds.), Cazadores de mar y tierra. Estudios recientes en arqueología fueguina. Editora Cultural Tierra del Fuego, Ushuaia, pp. 289-312.

Oría, J., Salemme, M., 2016. Visibilidad y preservación en Laguna Arturo,norte de Tierra del Fuego (Argentina). Un análisis geoarqueológico. Intersec. Antropol. 4.

Oría, J., Salemme, M., Fernández, M., 2014. Amalia 5: rol de los paisajes lagunares en la circulación humana en el interior de la estepa fueguina. Comechingonia 18, 135-157.

Oría, J., Salemme, M., Vázquez, M., 2016. Site formation processes through surface bone assemblages in the Fuegian steppe (Argentina). In: Tahonomies of trajectory. J. Archaeol. Anthropol. Sci. 8, 291-304 (special issue).

Oría, J., Bartoli, V., Fernández, M., Salemme, M. Fuentes, 2017. secuendarias intermitentes. El uso de materias primas líticas y el uso del espacio en Laguna Arturo, Tierra de Fuego. In: Libro de Resúmenes X Jornadas de Arqueología Patagonia (Puerto Madryn).
Rabassa, J., 2008. Late Cenozoic Glaciations in Patagonia and Tierra del Fuego. In: Rabassa, J. (Ed.), The Late Cenozoic of Patagonia and Tierra del Fuego. Elsevier Science (151204 pp.).

Recasens, C., Ariztegui, D., Maidana, N., Zolitschka, B., the PASADO Science Team, 2015. Diatoms as indicators of hydrological and climatic changes in Laguna PotrokAike (Patagonia) since the Late Pleistocene. Palaeogeogr. Palaeoclimatol. Palaeoecol. 417 (1), 309-319.

Rumbrich, U., Lange-Bertalot, H., Rumbrich, M., 2000. Diatomeen der Anden. Iconogr. Diatomol. 9, 1-672.

Salemme, M., Miotti, L., 2008. Archeological Hunter-Gatherer Landscapes since the Latest Pleistocene in Fuego-Patagonia. In: Rabassa, J. (Ed.), Late Cenozoic of Patagonia and Tierra del Fuego. Elsevier, Amsterdam, pp. 437-483.

Salemme, M., Santiago, F., 2017. Qué sabemos y qué no sabemos de la presencia humana durante el Holoceno medio en la estepa fueguina. In: Vazquez, M., Elkin, D., Oría, J. (Eds.), Patrimonio a orillas del mar: arqueología del litoral atlántico de Tierra del Fuego. Editora Cultural Tierra del Fuego, pp. 75-86.

Santiago, F.C., 2013. La ocupación humana del norte de Tierra del Fuego durante el Holoceno medio y tardío. Editora Cultural Tierra del Fuego (459 pp).

Stafford, C.R., 1995. Geoarchaeological perspectives on paleolandscapes and regional subsurface archaeology. J. Archaeol. Method Theory 2 (1), 69-104.

Stuiver, M., Reimer, P.J., Reimer, R.W., 2014. Calib Radiocarbon calibration 7.0. World Wide 478 Web. http://calib.qub.ac.uk/calib/.

Tilley, C., 1994. A phenomenology of landscape. Places, Paths and Monuments. Berg publishers, Oxford (UK) and Providence (USA).

Tuhkanen, S., 1992. The climate of Tierra del Fuego from a vegetation geographical point of view and its ecoclimatic counterparts elsewhere. Acta Bot. Fenn. 145, 1-64.

Wille, M., Maidana, N.I., Schäbitz, F., Fey, M., Haberzettl, T., Janssen, S., Lücke, A., Mayr, C., Ohlendorf, C., Schleser, G.H., 2007. Vegetation and climate dynamics in southern South America: the microfossil record of Laguna Potrok Aike, Santa Cruz, Argentina. Rev. Palaeobot. Palynol. 146, 234-246. 